\title{
Antibody and T Cell Responses of Patients with Adenocarcinoma Immunized with Mannan-MUC1 Fusion Protein
}

\author{
Vaios Karanikas, ${ }^{*}$ Le-Ann Hwang, ${ }^{*}$ Julian Pearson, ${ }^{*}$ Chin-Swee Ong, ${ }^{*}$ Vasso Apostolopoulos, ${ }^{*}$ Hilary Vaughan, ${ }^{*}$ \\ Pei-Xiang Xing, ${ }^{*}$ Gary Jamieson, ${ }^{*}$ Geoffrey Pietersz, ${ }^{*}$ Brian Tait, ${ }^{\ddagger}$ Russell Broadbent, ${ }^{\S}$ Grenville Thynne, ${ }^{\S}$ \\ and lan F.C. McKenzie* \\ *Immunology and Vaccine Laboratory, The Austin Research Institute, Heidelberg 3084, Victoria, Australia; ${ }^{\ddagger}$ Tissue Typing Laboratory, \\ Royal Melbourne Hospital, Victoria 3050, Australia; and ${ }^{\S}$ Allamanda Medical Centre, Queensland, Australia
}

\begin{abstract}
Mucin 1 (MUC1) is a large complex glycoprotein that is highly expressed in breast cancer, and as such could be a target for immunotherapy. In mice, human MUC1 is highly immunogenic, particularly when conjugated to mannan, where a high frequency of $\mathrm{CD8}^{+} \mathrm{MHC}$-restricted cytotoxic $\mathrm{T}$ lymphocytes is induced, accompanied by tumor protection. On this basis, a clinical trial was performed in which 25 patients with advanced metastatic carcinoma of breast, colon, stomach, or rectum received mannan-MUC1 in increasing doses. After 4 to 8 injections, large amounts of IgG1 anti-MUC1 antibodies were produced in 13 out of 25 patients (with antibody titers by ELISA of 1/320-1/20,480). Most of the antibodies reacted to the epitopes STAPPAHG and PAPGSTAP. In addition, $T$ cell proliferation was found in 4 out of 15 patients, and CTL responses were seen in 2 out of 10 patients. Mannan-MUC1 can immunize patients, particularly for antibody formation, and to a lesser extent, cellular responses. It remains to be seen whether such responses have antitumor activity. (J. Clin. Invest. 1997. 100: 2783-2792.) Key words: cancer • vaccine • epitopes • phase I trial $\cdot$ muc1 $\bullet$ immunotherapy
\end{abstract}

\section{Introduction}

Normal and malignant mammary epithelial cells express and secrete high molecular weight mucin glycoproteins that are extensively glycosylated, and are highly immunogenic in mice (14). More specifically, in breast cancer, identification of the cDNA for a ubiquitously expressed mucin, Mucin 1 (MUC1; $5-7),{ }^{1}$ led to the investigation of the means of presenting

\footnotetext{
Address correspondence to Professor Ian F.C. McKenzie, The Austin Research Institute, Studley Rd., Heidelberg 3084, Victoria, Australia. Phone: +61-3-92870-666; FAX: +61-3-92870-600; E-mail: ifc_mckenzie@muwayf.unimelb.edu.au

Received for publication 14 March 1997 and accepted in revised form 25 September 1997.
}

1. Abbreviations used in this paper: CTL, cytotoxic T lymphocyte CTLp, CTL precursors; FP, fusion protein; GM, growth medium; HRP, horeseradish peroxidase; M-FP, mannan fusion protein; MUC1, mucin 1; SI, stimulation index; VNTR, variable number of tandem repeats.

J. Clin. Invest.

(C) The American Society for Clinical Investigation, Inc. 0021-9738/97/12/2783/10 \$2.00

Volume 100, Number 11, December 1997, 2783-2792

http://www.jci.org
MUC1 peptides to induce meaningful antitumor responses, the focus being on generating $\mathrm{CD}^{+}$cytotoxic $\mathrm{T}$ lymphocytes (CTL). In breast cancer, MUC1 has a 10-40-fold increase in expression, and its structure is altered so that new carbohydrate epitopes are expressed and peptide epitopes are exposed $(2,8)$. Immunogenicity of MUC1, at least for antibody production in mice, resides in the sequence APDTRPA in the extracellular variable number of tandem repeat region (VNTR), which consists of multiple repeats of 20 amino acid-containing peptides (PDTRPAPGSTAPPAHGVTSA; 9-11). Furthermore, in a study that brought together murine and human studies of MUC1, CTL lines produced from the draining lymph nodes of breast cancer patients could be inhibited with antibodies directed against this APDTR region (12). In other studies, $\mathrm{T}$ cells could be isolated from the lymph nodes of patients with breast, pancreatic $(13,14)$, and ovarian cancer $(15)$, and from a patient with multiple myeloma (16). In these studies, after restimulation in vitro, CTLs were generated that could kill, in an MHC-unrestricted manner, breast and pancreatic tumor cells, demonstrating that precursor CTLs exist in the lymph nodes of cancer patients (17). Thus, the aim of MUC1 immunotherapeutic protocols is to stimulate the expansion of the CTL precursors (CTLp) to produce functional and useful immune response against $\mathrm{MUC1}^{+}$cancers.

We have previously used MUC1 fusion protein (consisting of five VNTR repeats linked to conventional carriers) for cancer immunotherapy in mice, and have found that antibodies could readily be generated, but no CTL to VNTR and poor tumor protection (18). By contrast, a high frequency of CTLp occurred when MUC1 fusion protein was chemically conjugated to mannan (4). Furthermore, it was found that H-2-restricted cytotoxic immune responses in mice were generated when the oxidized form of M-FP was used, in contrast to the humoral responses that occurred with the reduced form of M-FP $(19,20)$. These findings in mice, together with the documented CTL responses in cancer patients against MUC1, led us to investigate the immune responses of patients with adenocarcinoma immunized with oxidized M-FP in a phase I study, in which there was no evidence of toxicity or autoimmunity (Ong et al., manuscript submitted for publication). We report on the nature of the $\mathrm{B}$ and $\mathrm{T}$ cell responses found.

\section{Methods}

Patients and samples. 25 patients with metastatic adenocarcinoma were immunized with M-FP; the cancers were in breast $(n=8)$, colon $(n=9)$, rectum $(n=7)$ and stomach $(n=1)$. Injections were given subcutaneously at weeks $1,2,3,4,7,9,11$, and 13 , with doses ranging from 10 to $500 \mu \mathrm{g}$ (Table I), and bleeding at weeks 0,5 , and 14 . There were 13 males and 12 females, and the mean age was $68.2 \pm 12.5$ yr. 9 patients received 4 injections, and 16 received the full course of 8 injections. Serum samples from patients and normal subjects were col- 


\begin{tabular}{|c|c|c|c|c|c|c|c|}
\hline \multirow[b]{2}{*}{ Patient no. } & \multirow[b]{2}{*}{ Site of disease } & \multirow[b]{2}{*}{ No. of injections } & \multirow[b]{2}{*}{ Dose per injection } & \multicolumn{4}{|c|}{ MHC type } \\
\hline & & & & HLA-A & HLA-B & HLA-C & HLA-DRB1 \\
\hline & & & $\mu g$ & & & & \\
\hline 1 & Colon & 8 & 10 & 2,24 & 27,44 & 2,5 & NA \\
\hline 2 & Breast & 4 & 10 & 2,24 & 7,57 & 6,7 & NA \\
\hline 3 & Breast & 8 & 10 & 1,2 & 8,57 & 6,7 & 03,07 \\
\hline 4 & Rectum & 4 & 50 & 2,11 & 13,27 & 2,6 & 04,13 \\
\hline 5 & Stomach & 8 & 50 & 2,3 & 7,27 & 2,7 & 02 \\
\hline 6 & Colon & 4 & 50 & 1,3 & 7,8 & 7,7, or $\mathrm{X}$ & 03,04 \\
\hline 7 & Colon & 4 & 50 & 2,26 & 13,55 & 3 & NA \\
\hline 8 & Breast & 8 & 100 & 1,11 & 8,35 & 4,7 & 0103, 03 \\
\hline 9 & Rectum & 4 & 100 & 2 & NA & 27,44 & NA \\
\hline 10 & Colon & 8 & 100 & 1,24 & 37,51 & 1,6 & 04,11 \\
\hline 11 & Colon & 4 & 150 & 2,25 & 18,60 & 3 & NA \\
\hline 12 & Rectum & 8 & 150 & $11.1,26$ & 27,44 & 1 & 01,09 \\
\hline 13 & Colon & 8 & 150 & 2,3 & 7,51 & $7, X$ & 02,07 \\
\hline 14 & Colon & 8 & 200 & 1,3 & 7,51 & 7 & 03 \\
\hline 15 & Rectum & 8 & 200 & 1,2 & 8,60 & 3,7 & 03,04 \\
\hline 16 & Colon & 4 & 200 & NA & NA & NA & NA \\
\hline 17 & Breast & 8 & 300 & 1,29 & 44,44, or $X$ & 7 & 07,11 \\
\hline 18 & Rectum & 8 & 300 & 2,25 & 7,58 & 7 & 04,13 \\
\hline 19 & Rectum & 4 & 300 & 3,26 & 38,65 & 8 & NA \\
\hline 20 & Breast & 8 & 400 & 2,3 & 7,27 & 2,7 & NA \\
\hline 21 & Breast & 8 & 400 & $2,11.1$ & 27,55 & 1,2 & 04,11 \\
\hline 22 & Rectum & 8 & 400 & $1,11.1$ & 8,44 & 5,7 & 03 \\
\hline 23 & Breast & 8 & 500 & 2,33 & 7,65 & 7,8 & NA \\
\hline 24 & Colon & 8 & 500 & 26,32 & 51,56 & 1 & 11,6 , or 11 \\
\hline 25 & Breast & 4 & 500 & 1,33 & 57,57 , or $\mathrm{X}$ & 3,6 & NA \\
\hline
\end{tabular}

NA, not available; $X$, not typed.

lected, aliquoted, and stored at $-20^{\circ} \mathrm{C}$. $\mathrm{PBMC}$ were purified from heparinized blood by centrifugation with Ficoll-Paque obtained from Pharmacia LKB Biotechnology Inc. (Uppsala, Sweden) and kept frozen.

Peptides and fusion protein. Human MUC1-GST fusion protein (FP) containing five VNTR repeats of sequence (PAHGVTSAPDTRPAPGSTAP) was expressed in Escherichia coli, purified, and chemically conjugated to mannan (M-FP) $(4,21)$. GST was cleaved from the fusion protein using the site-specific protease factor Xa obtained from Boehringer Mannheim (Mannheim, Germany), and is referred to hereforth as VNTR. The peptides p1-30 (PDTRPAPGSTAPPAHGVTSAPDTRPAPGST) and Cp13-32 (C-PAHGVTSAPDTRPAPGSTAP) were synthesized using a Model 430A automated peptide synthesiser (Applied Biosystems, Inc., Foster City, CA; 22, 23).

ELISA. Anti-MUC1 antibodies were measured by ELISA against VNTR. ELISA plates, supplied by Greiner Labortechnik (Greiner $\mathrm{GmbH}$, Frickenhausen, Germany), were coated with $50 \mu \mathrm{l}$ of a $10 \mu \mathrm{g} /$ $\mathrm{ml}$ antigen solution in $0.05 \mathrm{M}$ carbonate buffer, $\mathrm{pH} \mathrm{9.6,} \mathrm{for} 20 \mathrm{~h}$ at $4^{\circ} \mathrm{C}$, washed twice with PBS- $0.1 \%$ Tween 20 and PBS, and nonspecific binding-blocked for $20 \mathrm{~h}$ at $37^{\circ} \mathrm{C}$ with $5 \%$ HSA obtained from ICN Biomedicals, Inc. (Irvine, CA) in PBS. Initial difficulties with the presence of high background levels were overcome when the ELISA plates were blocked with 5\% HSA rather than with 5\% BSA for reasons described previously $(24,25)$. The plates were washed, and diluted serum (1:40) was added in 1\% HSA-PBS. The plates were then incubated for $2 \mathrm{~h}$ at $37^{\circ} \mathrm{C}$, followed by six washes with PBS- $0.1 \%$ Tween 20 and four with PBS. Isotype and class-specific sheep anti- human Ig labeled with horseradish peroxidase (HRP) obtained from Silenus Labs (Hawthorn, Australia) and diluted to 1:1,500 in 1\% HSA-PBS were individually added to the plates for $2 \mathrm{~h}$ at $37^{\circ} \mathrm{C}$. The plates were washed, and anti-MUC1 antibodies were detected using $0.03 \%$ 2,2'-azino-di (3-ethylbenzthiozoline sulfonate) in $0.1 \mathrm{M}$ citrate buffer, $\mathrm{pH} 4.0$, containing $0.02 \% \mathrm{H}_{2} \mathrm{O}_{2}$. Absorbance was measured at $405 \mathrm{~nm}$ using an ELISA plate reader. Sera were considered to be positive when the OD reading was greater than the mean +3 SD of the 99 normal sera samples tested. Serum titers were determined at the highest serum dilution with an absorbance value $<0.12$ $\mathrm{nm}(26)$.

Epitope mapping. Epitopes were mapped using the pepscan method (27). The following modifications, however, were applied because of the high backgrounds obtained when the method reported by the company was followed. MUC1 peptides were synthesized on polyethylene pins by Chiron Mimotopes (Clayton, Australia) and consisted of 20 overlapping 8-mer peptides of the 20-amino acid VNTR (e.g. PDTRPAPG, DTRPAPGS, TRPAPGST...APDTRPAP). Nonspecific binding by the pins was blocked using 5\% HSA, $1 \%$ ovalbumin, and $0.1 \%$ Tween 20 in PBS for $20 \mathrm{~h}$ at $4^{\circ} \mathrm{C}$. Serum samples were diluted 1:500 in 1\% HSA-PBS, and were incubated with the pins for $2 \mathrm{~h}$ on ice. This serum dilution was found to differentiate clearly the nonspecific background seen in polyclonal sera. Pins were washed six times with PBS-0.1\% Tween 20 and PBS, and HRPlabeled sheep anti-human IgG diluted 1:1,500 in 1\% HSA-PBS was added for $1 \mathrm{~h}$. Bound antibodies were detected by the addition of $0.03 \%$ 2,2' -azino-di (3-ethylbenzthiozoline sulfonate) in $0.1 \mathrm{M}$ citrate 
buffer, $\mathrm{pH} 4.0$, containing $0.02 \% \mathrm{H}_{2} \mathrm{O}_{2}$. The absorbance was measured at $405 \mathrm{~nm}$ using an ELISA plate reader.

BIAcore ${ }^{\mathrm{TM}}$ analysis. The rates of dissociation of anti-MUC1 antibodies from immobilized fusion protein were calculated using a BIAcore $^{\mathrm{TM}} 2000$ biosensor (Pharmacia LKB Biotechnology Inc.). Measurement of dissociation rates was preferred over affinity measurements since the sera were polyclonal, and standardization of the anti-MUC1 antibody concentration would rely on the bivalency and affinity of the antibodies. The experiments were performed at $20^{\circ} \mathrm{C}$. The buffer used was Hepes buffered saline consisting of $0.005 \% \mathrm{vol} /$ vol Surfactant P-20 (Pharmacia LKB Biotechnology Inc.), $0.01 \mathrm{M}$ Hepes, and $0.15 \mathrm{M} \mathrm{NaCl}$. The buffer flow rate was $10 \mu \mathrm{l} / \mathrm{min}$. Fusion protein was coupled to CM5 sensor chips using the amine coupling kit supplied by the company as described (28). Chips were regenerated with $10 \mathrm{mM}$ glycine- $\mathrm{HCl}(\mathrm{pH} 2.4)$. The results are presented as the time taken for $50 \%$ of the antibody to dissociate $(\mathrm{min})$.

HLA typing. 23 subjects were typed for HLA class I antigens by standard serological analysis of PBMC, and 15 patients were typed for HLA class II antigens by DNA analysis.

Proliferation assays. Frozen PBMC were used for T cell proliferation assays, and cells were cultured at $1 \times 10^{5}$ cells (six replicates) with MUC1 peptides Cp13-32 and p1-30 (100, 25, 6, and $1.5 \mu \mathrm{g} / \mathrm{ml})$ and VNTR $(10,2.5,0.6$, and $0.15 \mu \mathrm{g} / \mathrm{ml})$ in 96-well U-bottom plates (Becton Dickinson, San Jose, CA) in AIM-V medium obtained from GIBCO BRL (Gaithersburg, MD) supplemented with 5\% human AB serum, $100 \mathrm{IU} / \mathrm{ml}$ penicillin, $100 \mu \mathrm{g} / \mathrm{ml}$ streptomycin, $10 \mathrm{mM}$ Hepes, and $2 \mathrm{mM}$ L-glutamine. As a positive control, $1 \mu \mathrm{g} / \mathrm{ml}$ PHA was used (Sigma Chemical Co., St. Louis, MO). On day 3 of culture, $10 \%$ of the medium was replaced with fresh medium containing recombinant human IL-2 obtained from Genzyme Corp.(Cambridge, MA) to a final concentration of $5 \mathrm{U} / \mathrm{ml}$. On day 5 cultures were pulsed with $0.5 \mu \mathrm{Ci}\left[{ }^{3} \mathrm{H}\right]$ thymidine. Cells were harvested on day 6 , and $\left[{ }^{3} \mathrm{H}\right]$ thymidine incorporation was determined. Results are expressed as stimulation index units (SI) calculated as follows: experimental cpm (with antigen)/medium only. A proliferation response was considered to be positive when $\left[{ }^{3} \mathrm{H}\right]$ thymidine incorporation was significantly different (at $P \leq 0.05$ ) from that of the medium control.

$T$ cell cytotoxicity assays. CTL responses were determined by protocols 1 and 2. Protocol 1 consisted of $4 \times 10^{6}$ freshly thawed PBMCs cultured with $20 \mu \mathrm{g} / \mathrm{ml} \mathrm{M}-\mathrm{FP}$ in 24-well plates (Becton Dickinson) in $1 \mathrm{ml}$ of AIM-V medium supplemented with $100 \mathrm{IU} / \mathrm{ml}$ penicillin, $100 \mu \mathrm{g} / \mathrm{ml}$ streptomycin, $10 \mathrm{mM}$ Hepes, $2 \mathrm{mM}$ L-glutamine (growth medium; GM), and 10\% FCS. On day 3 of culture, recombinant human IL-2 was added for a final concentration of $10 \mathrm{U} / \mathrm{ml}$. Cytotoxicity was measured on day 9 by a standard ${ }^{51} \mathrm{Cr}$ release assay against Cp13-32- and p130 (20 $\mu \mathrm{M})$-pulsed autologous PBMC blasts cultured for $72 \mathrm{~h}$ with $1 \mu \mathrm{g} / \mathrm{ml}$ PHA in 10\% FCS-GM. NK killing was inhibited by incubating effector cells with a 20 -fold excess of cold $\mathrm{K} 562$ cells to hot targets. Percent specific ${ }^{51} \mathrm{Cr}$ release from each target was calculated as follows: ([experimental release - spontaneous release]/[maximum release - spontaneous release] $) \times 100$. A positive test occurred when the percent specific lysis was $\geq 10 \%$ and when the lysis on MUC1 peptide-pulsed targets differed by $\geq 1 \mathrm{SD}$ from the nonpeptide pulsed targets. Protocol 2 consisted of $4 \times 10^{6}$ freshly thawed PBMCs cultured with $20 \mu \mathrm{g} / \mathrm{ml}$ M-FP in 24-well plates in $1 \mathrm{ml}$ of $10 \%$ FCS-GM. On days 3 and 6 of culture, recombinant human IL-2 was added for a final concentration of $10 \mathrm{U} / \mathrm{ml}$, and on day 7, freshly thawed PBMC were pulsed with MUC1 peptides by resuspending at $4 \times 10^{6} \mathrm{cells} / \mathrm{ml}$ in $1 \%$ FCS-GM containing $50 \mu \mathrm{g} / \mathrm{ml}$ of $\mathrm{p} 1-30$, $50 \mu \mathrm{g} / \mathrm{ml} \mathrm{Cp} 13-32,3 \mu \mathrm{g} / \mathrm{ml}$ ß2-microglobulin (Sigma Chemical Co.), and $20 \mathrm{ng} / \mathrm{ml} \gamma \mathrm{IFN}$ obtained from Biosource International (Camarillo, CA) to induce expression of MHC class I molecules (29). Cells $(1 \mathrm{ml} /$ well $)$ were incubated for $2 \mathrm{~h}$ at $37^{\circ} \mathrm{C}$ in 24 -well plates, and nonadherent cells were discarded. Effector cells were collected by gentle pippetting, and were resuspended at $5 \times 10^{5}$ cells $/ \mathrm{ml}$ in $10 \%$ FCS-GM containing $10 \mu \mathrm{g} / \mathrm{ml} \mathrm{p} 1-30$ and $10 \mu \mathrm{g} / \mathrm{ml} \mathrm{Cp} 13-32.1 \mathrm{ml}$ of the cell suspension was added to the adherent cells. On days 9 and 12, recombinant human IL-2 was added to a final concentration of $10 \mathrm{U} / \mathrm{ml}$. Cyto- toxicity was measured on day 14 by a standard ${ }^{51} \mathrm{Cr}$ release assay as described above.

Statistics. Results are expressed as mean $\pm \mathrm{SD}$ and were analyzed using a Student's 2-tailed $t$ test; $P<0.05$ was regarded as significant. Correlation coefficients were calculated by Pearson's product moment to identify the significance of various indices compared.

\section{Results}

Clinical. The clinical aspects of the study are discussed elsewhere (Ong et al., manuscript submitted for publication). In short, there was low toxicity, however, as presented herein, most patients made a considerable anti-MUC1 antibody response. A few patients made HLA-restricted T cell proliferative and CTL responses.

Patients injected with mannan fusion protein $(M-F P)$ generate antibodies to MUC1. Serum samples from 99 normal subjects, from 9 patients receiving 4 injections of M-FP, and from 16 patients receiving 8 injections of M-FP over a period of 1-12 wk, were tested by ELISA for antibodies against VNTR (Fig. 1). Several findings were apparent. First, no antibodies to MUC1 could be detected in samples from the 99 normal subjects, nor could they be detected from patients before immunization (mean OD value of normal subjects, $0.12 \pm 0.11$; mean OD value of patients, $0.13 \pm 0.08)$. Therefore, in contrast to the findings of others ( 30 and Richards et al., manuscript submitted for publication), we were unable to demonstrate any preexisting anti-MUC1 antibodies. Second, after immunization, it was clear that large amounts of anti-MUC1 antibody were made by most of the patients. After 4 injections an OD of $0.43 \pm 0.49$ was obtained in 6 out of 25 patients $(24 \%)$, and after 8 injections the OD was $1.00 \pm 0.61$ in 11 out of 16 patients

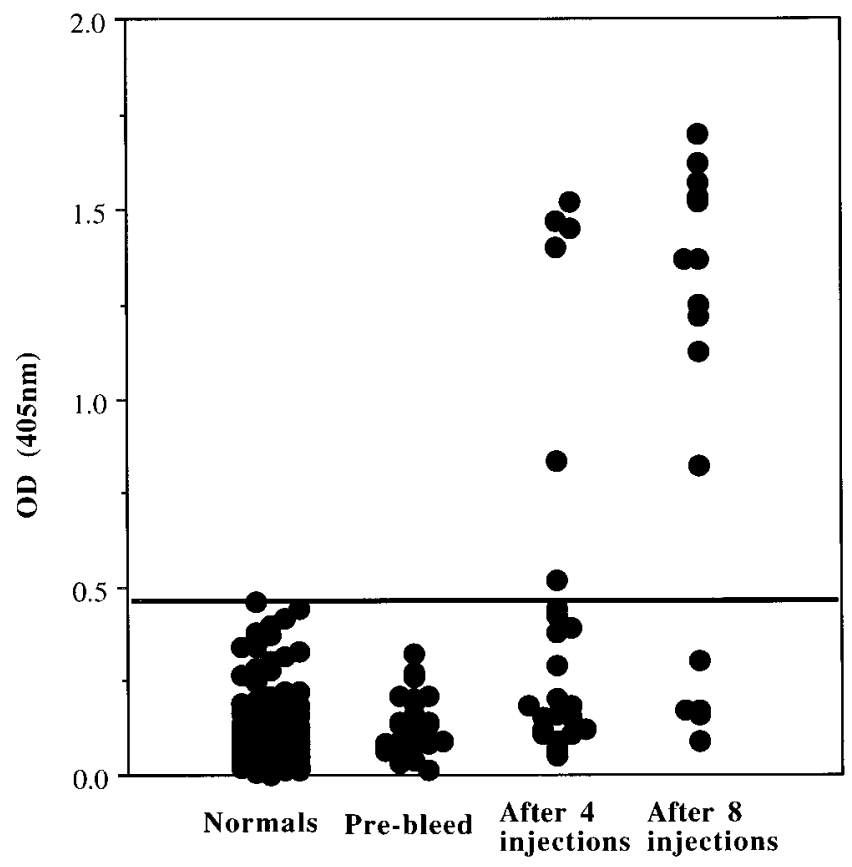

Figure 1. Anti-MUC1 responses in patients immunized with M-FP. Sera (1:40 dilution) from patients and normal subjects were tested by ELISA. Sera were tested before immunization (pre-bleed), after four, and after eight injections. The line at $\mathrm{OD}=0.465$ represents the mean +3 SD of 99 normal serum samples. 


\begin{tabular}{|c|c|c|c|c|c|}
\hline \multirow[b]{2}{*}{ Patient no. } & \multicolumn{3}{|c|}{ Immunization sample* } & \multirow[b]{2}{*}{ Titer $^{8}$} & \multirow[b]{2}{*}{ Pins } \\
\hline & Prebleed & 4 injections & 8 injections & & \\
\hline 8 & 0.04 & 0.38 & 1.00 & $1 / 640$ & No epitope identified \\
\hline 11 & 0.18 & 0.91 & NA & $1 / 640$ & Not tested \\
\hline 12 & 0.02 & 0.03 & 1.16 & $1 / 640$ & No epitope identified \\
\hline 13 & 0.02 & 0.06 & 0.54 & $1 / 320$ & STAPPAHG \\
\hline 14 & 0.02 & 0.18 & 0.90 & $1 / 320$ & No epitope identified \\
\hline 16 & 0.17 & 1.54 & NA & $1 / 1280$ & PAPGSTAP \\
\hline 17 & 0.00 & 0.01 & 1.00 & $1 / 640$ & STAPPAHG \\
\hline 18 & 0.08 & 0.20 & 1.09 & $1 / 640$ & No epitope identified \\
\hline 20 & 0.01 & 0.71 & 1.60 & $1 / 5120$ & STAPPAHG, PAPGSTAP \\
\hline 21 & 0.08 & 1.32 & 1.57 & $1 / 20480$ & PGSTAP, HGVTSA \\
\hline 22 & 0.03 & 0.08 & 1.41 & $1 / 1280$ & PAPGST \\
\hline 23 & 0.07 & 1.19 & 1.44 & $1 / 2560$ & No epitope identified \\
\hline 24 & 0.17 & 1.45 & 1.57 & $1 / 5120$ & STAPPAHG, PAPGSTAP, AHGVTSA \\
\hline
\end{tabular}

*OD reading $(405 \mathrm{~nm})$ of sera from each patient at a dilution of 1:40 as tested by ELISA against VNTR. A reading is positive if OD $>0.46$ (mean + $3 \mathrm{SD}$ of 99 normal sera). ${ }^{*}$ Patients positive for anti-MUC1 antibodies. ${ }^{\S}$ Antibody titer of the last serum sample obtained from each patient.

(69\%). This result was significant when compared with normal subjects $(\mathrm{OD}=0.12 \pm 0.11, P<0.001$; Table II). In total, 13 out of 25 injected patients were positive for anti-MUC1 antibodies. The OD values represent the amount of anti-MUC1 antibody at a dilution of 1:40, however, titrations of the serum revealed the antibodies to be of high titer (1/320-1/20,480; Fig. 2 and Table II). In addition, there was a correlation between the level of antibody produced and the immunizing dose of M-FP $\left(r^{2}=0.72\right)$. Of the 16 patients that received 8 injections, 5 immunized with a dose $>400 \mu \mathrm{g}$ generated specific antibodies with an $\mathrm{OD}>1.40,6$ patients injected with a dose of 100-300 $\mu \mathrm{g}$ generated antibodies with an OD between 0.54 and 1.20, and 5 patients that received a dose of $10-100 \mu \mathrm{g}$ generated antibodies with an OD $<0.15$ (Fig. 3). Hence, mannan MUC1 fusion protein in humans is a powerful immunogen for MUC1 antibody responses.

The strength of anti-MUC1 antibodies binding to MUC1 was examined using the BIAcore ${ }^{\mathrm{TM}}$ biosensor. Sera of patients with anti-MUC1 antibodies were tested for binding to FP immobilized on a carboxymethylated dextran matrix-coated gold sensor chip. It was evident that after immunization with M-FP, the antibodies generated bound strongly to MUC1. The half-

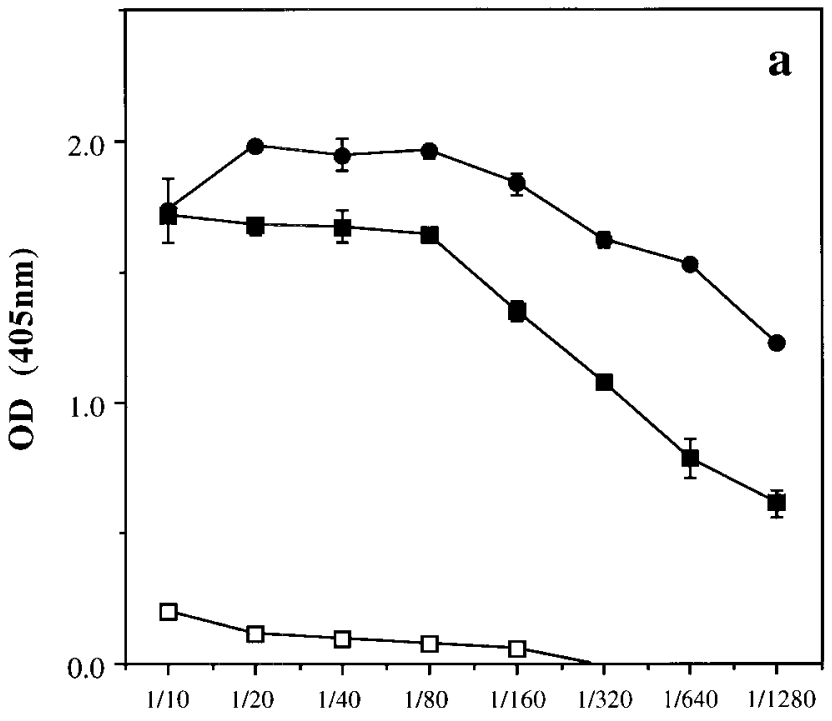

Antibody dilution

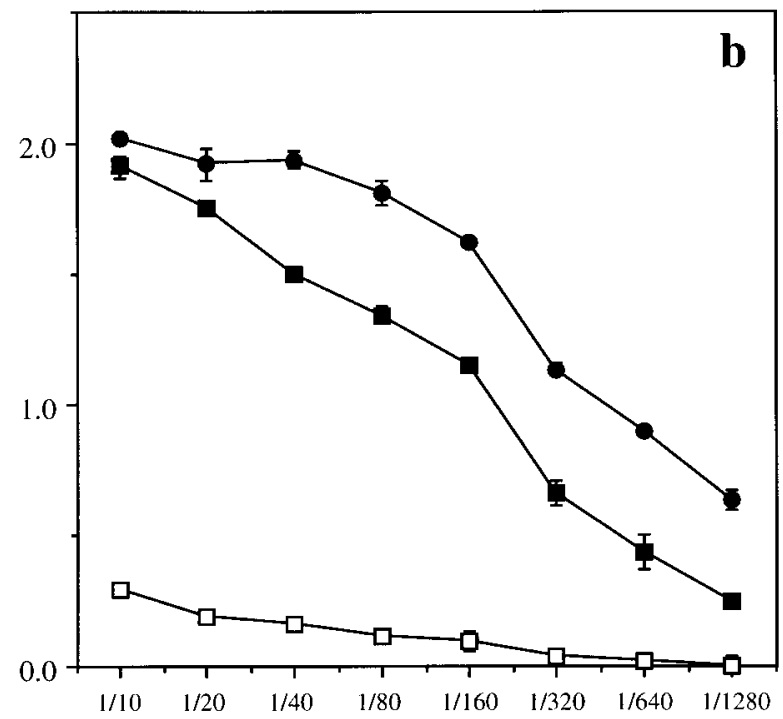

Antibody dilution

Figure 2. Titration of anti-VNTR antibodies. Serum samples from two immunized patients: $(a)$ patient 21; $(b)$ patient 24. Samples tested are represented as follows: before immunization $(\square)$; after four injections (ם); and after eight injections $(\boldsymbol{\bullet})$. 


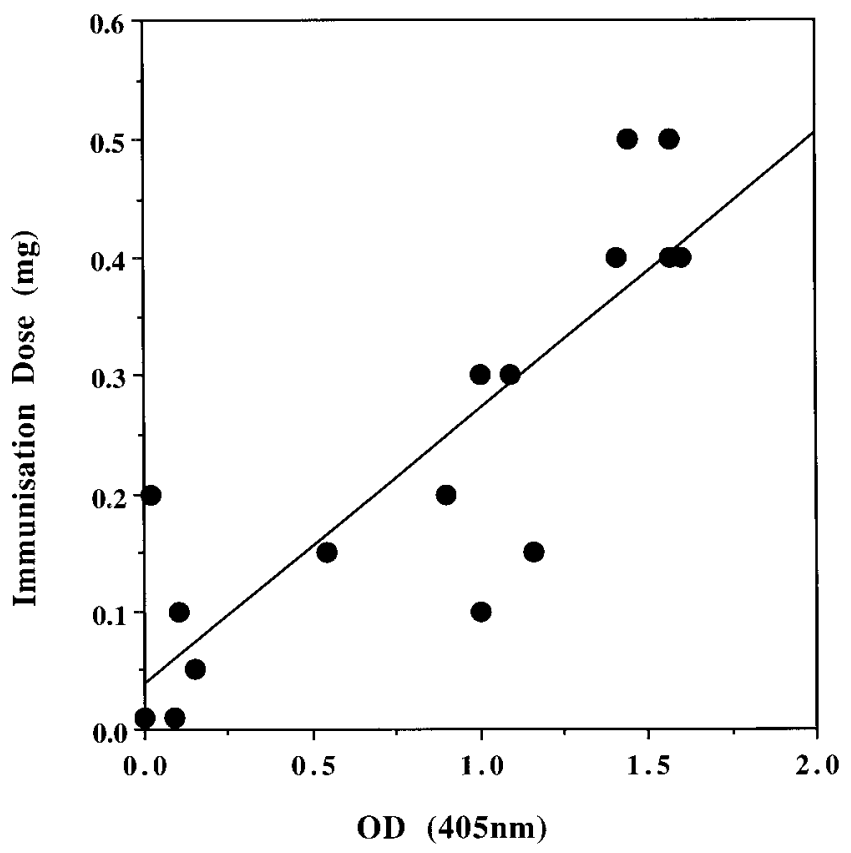

Figure 3. Correlation of the immunization dose ( $\mu \mathrm{g}$; y axis) with the OD value of serum sample (1:40 dilution; $\mathrm{x}$ axis); $r^{2}=0.72$.

life of the dissociation ranged from 12.3 to $167.4 \mathrm{~min}$, which compared favourably with the half-life generated for BC2 (109 min), a known monoclonal antibody that binds with high affinity to MUC1. Binding to FP on the BIAcore ${ }^{\mathrm{TM}}$ was only demonstrable in sera from immunized patients, and not from normal subjects (not shown). The time taken for half of the antibody to dissociate is a measure of the tightness of antibody binding to the immunogen, and is independent of the level of antibody in the serum.

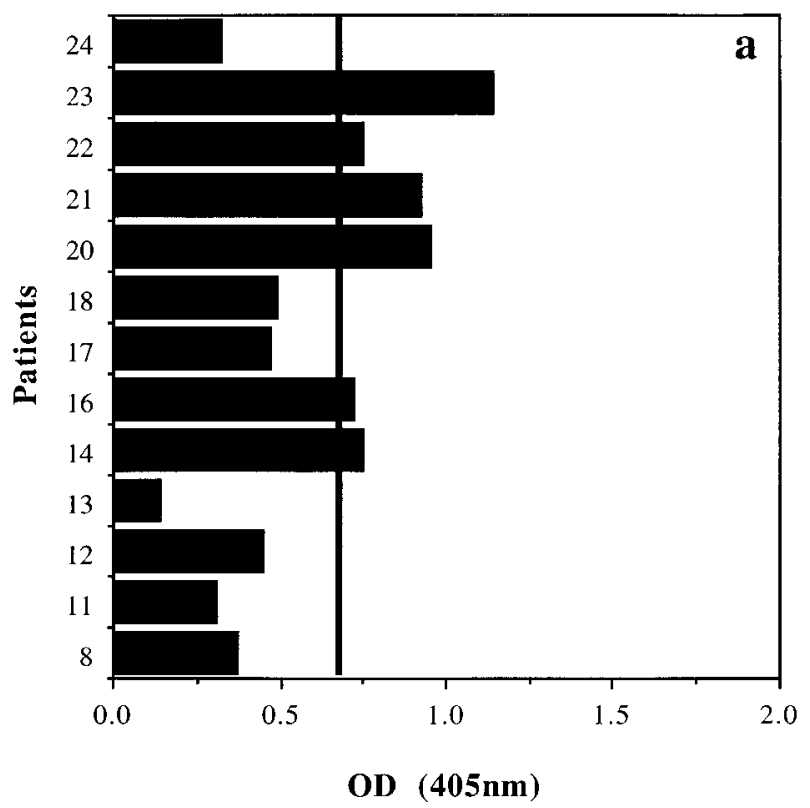

Isotype of the antibody response. The immunoglobulin class and subclasses were measured in patients with anti-MUC1 antibody responses: 6 out of 13 patients made low amounts of IgM antibodies after 4 injections, and there was weak $\operatorname{IgM}$ reactivity after 8 injections (Fig. $4 a$ ). Patients made IgG antibodies (data not shown), and in 12 out of 13 patients, most of the antibodies were of the $\gamma 1$ isotype (Fig. $4 b$ ). In particular, there were no $\gamma 2, \gamma 3$, or $\gamma 4$ antibodies found (data not shown). Furthermore, there were no $\operatorname{Ig} \mathrm{A}$ antibodies detected (data not shown). Thus, the predominant antibodies made were $\gamma 1$, the subclass mostly associated with $\mathrm{TH} 2$-type responses, which is in contrast with the TH1 type of responses seen in mice injected with oxidized M-FP (4).

Detection of amino acid epitopes by MUC1 antibodies. Although the antibody response of the patients to VNTR was polyclonal, discrete MUC1 peptide epitopes could be identified in seven patients. This identification was done using the pepscan method, wherein overlapping 8-mer peptides were synthesized and tested on 20 pins; each containing one amino acid different from the preceding pin (Table II). All 13 patients positive for anti-MUC1 antibodies were tested.

Three types of reactivity could be identified. First, in sera from patients $8,12,14,18$, and 23 , no reactivity could be detected. Most likely the antibodies in these sera were conformational and could not recognise the peptide structure as presented on the pins (Table II). Second, in sera from patients $13,16,17$, and 22 , reactivity could be detected against at least one MUC1 peptide, such as STAPPAHG, PAPGSTAP, or PAPGST (Table II). Finally, the third pattern of reactivity was seen in sera from patients 20,21 , and 24 , where the epitopes identified were the ones identified by the other sera in addition to PGSTAP, AHGVTSA, and HGVTSA. This reactivity could only be seen after immunization with M-FP, and not in the preimmunisation samples (Fig. 5).

Proliferative responses. The induction of $\mathrm{IgG} 1$ anti-MUC1 antibodies suggested the involvement of $\mathrm{T}$ cell help in the im-

Figure 4. Anti-MUC1 antibody class. y axis, patient no.; x axis, OD $(405 \mathrm{~nm})$. The line for each graph represents the mean $+3 \mathrm{SD}$ of $19 \mathrm{normal}$ sera. (a) IgM; (b) IgG1.

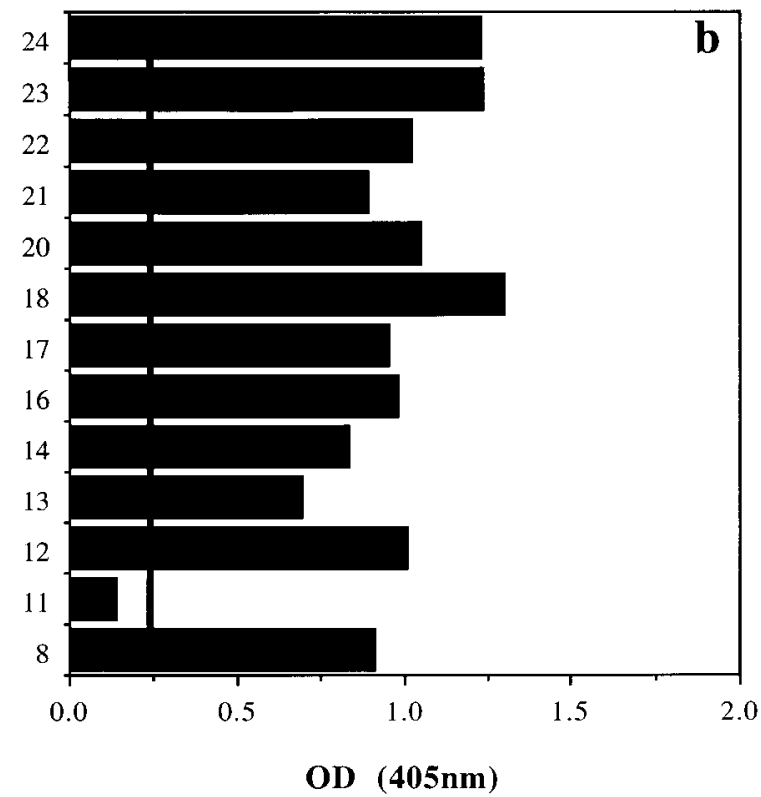



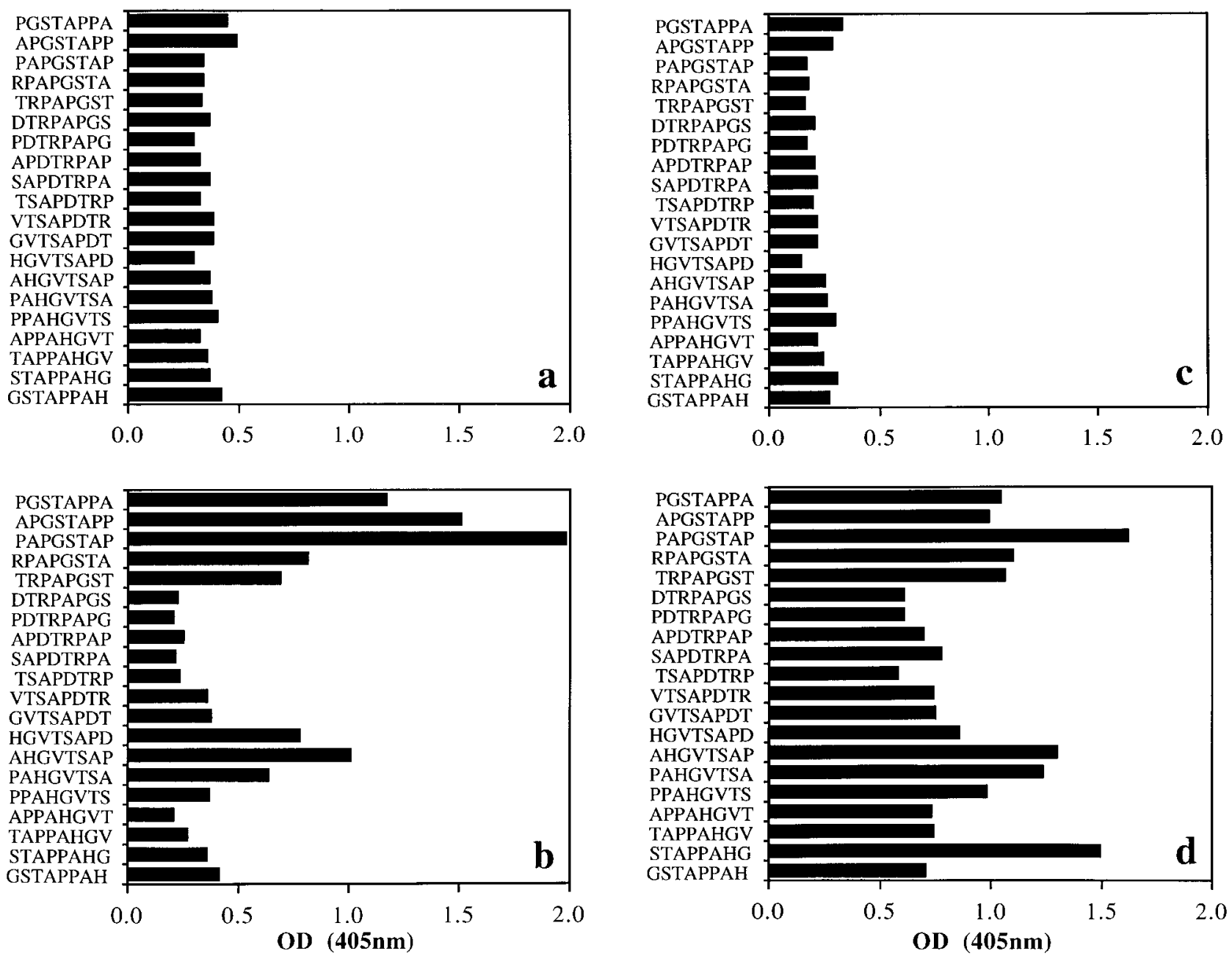

Figure 5. Testing of sera against overlapping 8-mer peptides synthesized on pins. OD (405 nm) of sera at 1:500 dilution is shown. Reactivity of serum from two patients. (a) pre-bleed sample of patient 21; $(b)$ after eight injections, sample of patient 21; $(c)$ pre-bleed sample of patient 24; $(d)$ after eight injections, sample of patient 24.

munological response of the patients. $\mathrm{T}$ cell proliferation was sought by examining the ability of PBMC (from immunized patients that received eight injections) to proliferate in vitro against MUC1 peptides.

PBMC from 4 out of 15 patients proliferated in response to MUC1 antigens with an increase in the stimulation index (Fig. 6). The SIs were quite variable; up to 120 in some cases, and 4 in others. Patient 15 generated very strong responses against all peptides after 4 injections. The SI ranged from 57 to $129 \mathrm{U}$, and these responses were significantly different from those generated by the cells from the prebleed sample $(P<0.005)$. The response, however, unexplainably disappeared after eight injections, and the patient currently has no evidence of recurrent disease (Ong et al., manuscript submitted for publication). Since all proliferation experiments were performed only once because of insufficient cell numbers, we were unable to repeat the experiment. Patient 8 , after 4 and 8 injections, generated proliferative responses against all peptides, and the SI ranged from 10 to $25 \mathrm{U}$ (Fig. $6 a$ ). When we compared the SI obtained against Cp13-32, a significant increase was found $(P<0.005)$ between the sample obtained after 8 injections compared with that after 4 injections. This patient has currently stable disease (Ong et al., manuscript submitted for publication). Patients 14 and 22 generated moderate proliferative responses. Proliferation was detected only after 8 injections, and this was against all antigens for patient 14 or against Cp13-32 for patient 22 (Fig. 6, $b$ and $c$ ). Interestingly, patient 22 showed signs of stable disease with improvement on their tumor loading.

A correlation among the proliferative response, the immunizing dose, the antibody response, and the HLA phenotype was sought (Table III). No particular pattern emerged when the proliferative response was compared with the dose of immunization or the levels of anti-MUC1 antibodies produced. All four patients, however, had HLA-A1 and DR3 MHC antigens, and HLA-B8 was present in three out of four patients.

Cytotoxic T cell responses. CTL responses of PBMC from immunized patients were examined initially with protocol 1 as described in Methods. No CTL, however, were detected in samples from all 25 patients (not shown), and it became evident that only one stimulation in vitro was not sufficient to detect the low CTLp frequency present in peripheral blood cells of patients. When protocol 2 was used, specific CTL responses 

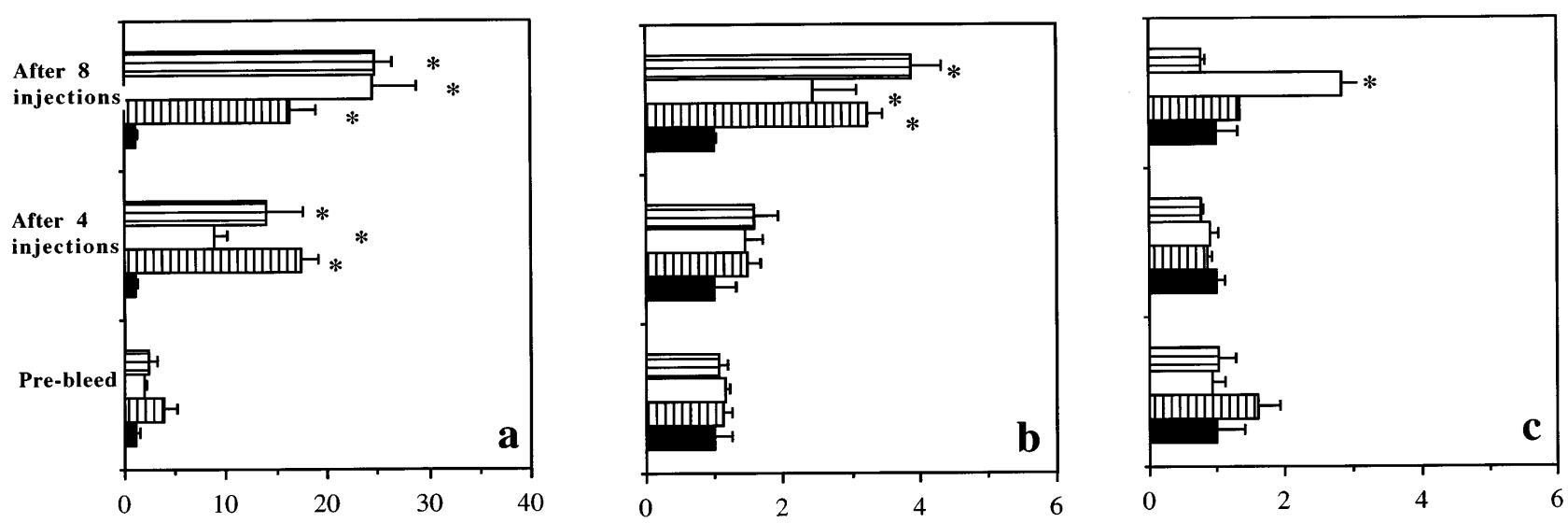

Figure 6. SI units shown in patient $8(a)$, patient $14(b)$, and patient $24(c)$. PBMC were exposed to p1-30 (horizontally hatched bars), Cp13-32 (white bars), VNTR (vertically hatched bars), or no antigen (black bars). Samples were tested before immunization (pre-bleed), after four injections, and after eight injections. Proliferation was assessed after $6 \mathrm{~d}$. The data represent SI units at the following concentrations of antigen: VNTR, $10 \mathrm{ng} / \mathrm{ml}$; $1-30,25 \mu \mathrm{g} / \mathrm{ml}$, and Cp13-32, $25 \mu \mathrm{g} / \mathrm{ml}$. * $P \leq 0.005$ when compared with the pre-bleed sample.

were generated in two patients (Fig. 7). Only 10 patients could be assessed, since there were insufficient numbers of PBMC from all. In 2 out of 10 patients (patients 4 and 13), CTL killed autologous PHA-blast targets pulsed with MUC1 antigens (29.1 and $18.4 \%$, respectively, at an effector-to-target ratio of 36:1) and both patients were HLA-A2. The CTL were specific as there was no killing in the absence of peptides, and killing by NK was blocked with unlabeled K562 cells. Furthermore, responses could only be generated from the patients, and only after immunization, since preimmunization samples and samples from normals tested under the same conditions did not generate any CTL (data not shown).

\section{Discussion}

In adenocarcinomas, and in particular breast cancer, mucin molecules have been recognized as potential targets for immunotherapy. MUC1, found in cancers of the gastrointestinal tract, ovary, breast, pancreas, kidney, and lung, shows a 1040-fold increase in expression, and there can be substantial alterations so that new carbohydrate and protein epitopes appear (for review see reference 31 ). Our laboratory has previously demonstrated that MUC1 can be immunogenic in mice, and depending on the chemical form used, either antibody- or MHC-restricted CTL responses can be generated. We have in the past conducted a phase I clinical trial using a MUC1 peptide (Cp13-32) coupled to diphtheria toxoid (32); weak antibody and proliferative responses were detected, indicating the need for improving the immunogen used and its form of delivery. Recently we demonstrated that conjugating MUC1 to mannan leads to improved cellular responses (4), and now we report our findings in the generation of immune responses in patients with adenocarcinoma injected with M-FP.

Our clinical study indicated that M-FP is highly immunogenic in humans, since patients generated humoral responses to MUC1 as 13 of 25 patients showed significant levels of hightitered, high-binding anti-MUC1 antibodies. The levels of IgG1 antibody showed a significant correlation with the immunization dose; the higher the dose, the more antibody found. The amount of antibody produced to MUC1 was greater than that previously described in trials involving MUC1 carbohydrate immunogens $(26,33-36)$, although all of these antibodies are against carbohydrate epitopes, not MUC1 peptides, as in our study. It was of interest to note that the anti-MUC1 antibodies in our study were found in similar amounts to those found in autoimmune diseases such as primary biliary cirrhosis and insulin-dependent diabetes mellitus $(37,38)$. Furthermore, antibodies were found to be of the IgG1 subclass, and titers were up to $1 / 20,480$. This subclass of antibody is found predominantly in a TH2-type response (39), and includes a predominant feature of this response in humans as further discussed below.

It should be noted that no anti-MUC1 antibodies were detected in any of the preimmunization samples using our ELISA protocol, but only after immunization with M-FP. In

Table III. Comparison of Cellular Responses with Immunization Dose, HLA, and Antibody Levels

\begin{tabular}{|c|c|c|c|c|c|c|c|}
\hline \multirow[b]{2}{*}{ Patient } & \multirow[b]{2}{*}{$\begin{array}{c}\text { Immunization } \\
\text { dose }\end{array}$} & \multicolumn{3}{|c|}{ HLA } & \multirow[b]{2}{*}{$\mathrm{Ab}^{*}$} & \multirow[b]{2}{*}{$\begin{array}{c}\text { Stimulation } \\
\text { index }\end{array}$} & \multirow[b]{2}{*}{ CTL } \\
\hline & & A & B & DR & & & \\
\hline & $\mu g$ & & & & & & \\
\hline 8 & 100 & 111 & 835 & 3 & 1.00 & $16.0-25.0$ & -2.0 \\
\hline 14 & 200 & 13 & 751 & 3 & 0.90 & $2.5-4.0$ & NT \\
\hline 15 & 200 & 12 & 860 & 3 & 0.02 & $57.0-129.0^{\mathbb{T}}$ & 7.9 \\
\hline 22 & 400 & 111.1 & 844 & 3 & 1.41 & $0.8-2.9$ & -2.0 \\
\hline 4 & 50 & 2,11 & 13,27 & 4,13 & 0.33 & NT & 29.1 \\
\hline 13 & 150 & 2,3 & 7,51 & 2,07 & 0.54 & $0.8-1.2$ & 18.4 \\
\hline
\end{tabular}

*Antibody reactivity to VNTR by ELISA. Numbers represent OD reading (405 nm). ${ }^{\ddagger}$ Range of stimulation index (SI units) of PBMC against MUC1 antigens as represented in Fig. $6 .{ }^{8}$ Percent specific chromium release of PHA blast autologous targets pulsed with MUC1 peptides as described in Methods. E/T is 36:1. "This patient generated a proliferative response after only four vaccinations that disappeared after eight vaccinations. The reasons for this result are presented in the text. NT, not tested. 

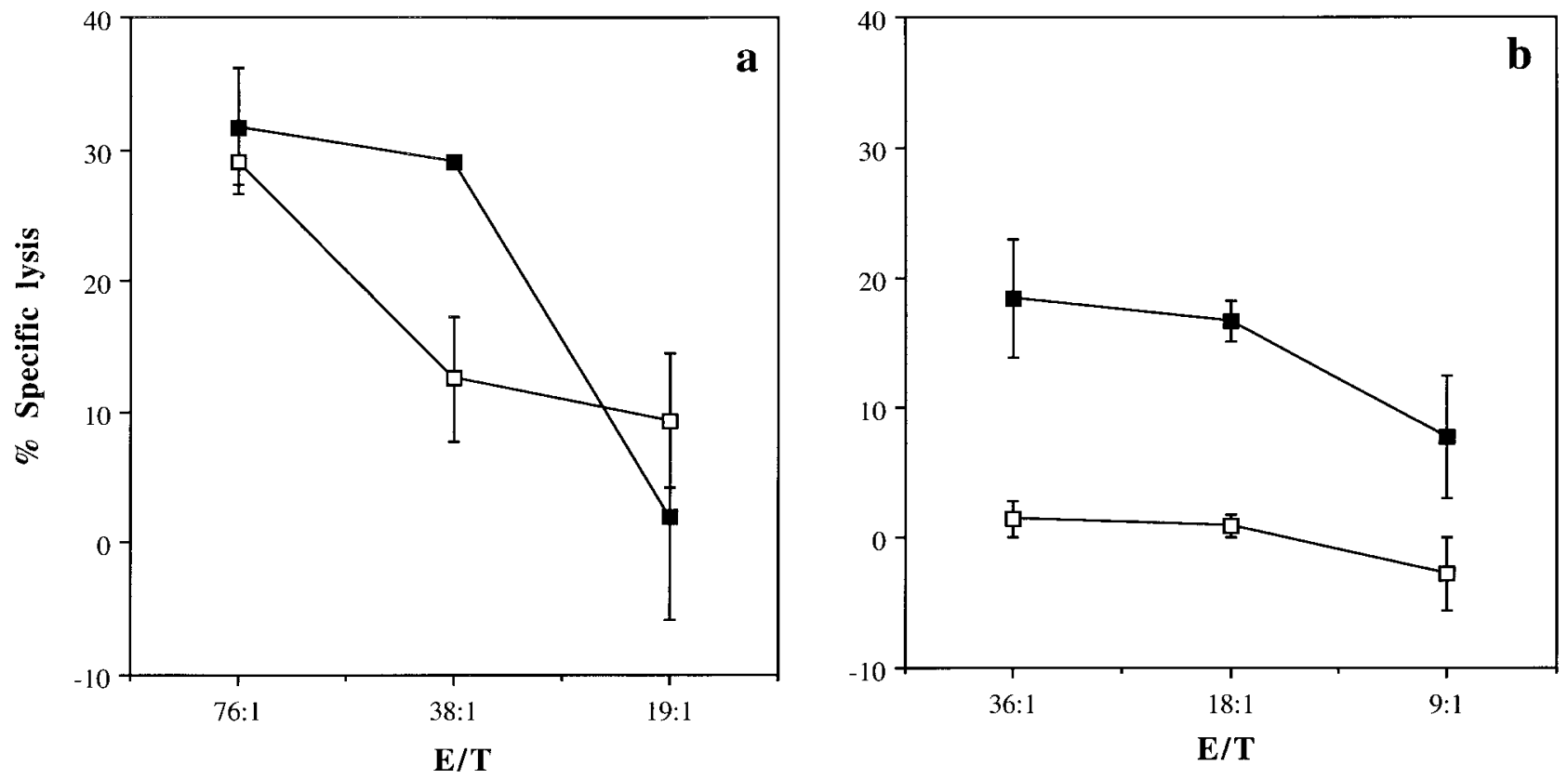

Figure 7. CTL responses of PBMC from immunized patient 4 ( $a$ ) and patient 13 (b). Autologous PHA blasts were loaded with peptide ( $\mathbf{\square})$ or no peptide $(\square)$. E/T ratio, $x$ axis; \% specific lysis, y axis.

this regard, our findings differ from others whereby antibodies from patients with adenocarcinoma were detected either in a free state $(30,40)$, or were complexed with MUC1 as an immune complex (41). These MUC1 antibodies have been identified to be either of the IgM class (30 and Richards et al., manuscript submitted for publication), or both $\operatorname{IgG}$ and $\operatorname{IgM}(42)$.

The anti-MUC1 antibodies we found detected at least two adjacent regions in the tandem repeat of MUC1 (STAPPAHG and PAPGSTAP peptide epitopes), and recently IgM antibodies that reacted with STAPPAHG or shorter peptides of it were found in ovarian cancer patients (43). Furthermore, in our study, some patients also showed reactivity to PGSTAP, HGVTSA, PAPGST, and AHGVTSA. Our findings differ from those recognizing APDTR as the immunodominant region identified by mouse antibodies to human MUC1 (44), and of antibodies generated in monkeys immunized with human M-FP (Vaughan et al., manuscript submitted for publication). Although APDTR can be the most immunogenic region of MUC1 when used in mice, variation in antibody reactivity against multiple epitopes suggests that MUC1 peptides are not equally immunogenic to all individuals. The most likely reason for this fact is the way that these peptides are presented by HLA-DR molecules to helper T cells for inducing antibodies. There was, however, no correlation of antibody response and HLA-DR alleles. Furthermore, when the sera were tested for reactivity against breast cancer sections by immunoprecipitation or for binding to breast cancer cell lines by FACS, we could not identify any difference in the intensity of binding between the preimmunization and postvaccination samples (not shown). We attribute this finding to the presence of the natural anti-Gal antibodies present in humans that can cross-react with MUC1 $(24,25)$, suggesting the existence of strongly tolerant mechanisms regulating the immune response in vivo. We also note that the MUC1 epitopes recognized by the patients' antibodies could be detected in phenyl GalNAc-treated breast cancer cell lines $(9,21)$.

Induction of $\mathrm{H}-2-$ restricted CTL responses in mice to MUC1 conjugated to mannan was recently described (4, 19, 45 ), and in these studies 2 out of 10 patients generated CTL responses. These responses were peptide-specific and restricted to self MHC molecules in patients with HLA-A2 (patient 4, A2 A11; patient 13, A2 A3). Inhibition of NK killing with K562 cells ensured that lysis was specific for the HLA-A2 peptide complex. Although the sample number is too small to conclude that the response to HLA-A2 was restricted, we note that CTL from HLA-A2.1 transgenic mice can recognize two MUC1 peptides (STAPPAHGV- and APDTRPA-containing peptides) presented by human EBV cells expressing HLA-A2, and also endogenously produced peptides in the MCF-7 cell line (46). The low number of patients generating a CTL response was possibly due to the technique used, whereby only two stimulations in vitro were used, combined with long delays in obtaining the samples for processing. Other groups assessing clinical trials using tumor antigens such as MAGE or measuring CTL responses in cancer patients, undergo multiple in vitro restimulation cycles to select for the preexisting CTLs $(47,48)$.

A proliferative cellular response to MUC1 occurred in 4 out of 15 patients, indicating that M-FP could stimulate both CD4 and CD8 T cells in vivo. Furthermore, there was a significant HLA association in that all of the patients showing a proliferative response were HLA-A1 and DR3, compared with $20 \%$ in the community and $40 \%$ of patients in this study. Also, HLA-B8 was present in $75 \%$ of the patients with a proliferative response compared with $9 \%$ in the patients that did not proliferate. Thus, the HLA-A1, B8, and DR3 alleles are associated with proliferative $\mathrm{T}$ cell responses, and appear to occur together. The implications of these relationships are twofold. 
First, since we were unable to measure the phenotype of the responding cells, the presence of these particular MHC I antigens suggests that the proliferating cells are CD8 T cells. Second, the association with DR3 indicates that there might be restrictive elements in the type of immune response generated by patients with adenocarcinoma, as is the case with the MAGE antigen in patients with melanoma (49). No particular region of the MUC1 antigen, however, could be selected as an MHC class II epitope according to known binding motifs (50).

Induction of immune responses in phase I trials using peptide-based immunogens has been very difficult, with the exception of one trial for HIV (51). In that trial, patients received recombinant gp160 in alum and made antibodies to various epitopes of gp160. T cell proliferative responses, but no CTLs, were obtained against gp160 in 70\% of the patients. In other studies where melanoma patients were injected with MAGE3.A1 peptide (52), antitumor responses were detected in 3 out of 6 patients, but no evidence of a humoral or CTL response was observed. In a recent study 63 patients with adenocarcinoma were immunized with an 105-amino acid MUC1 peptide mixed with BCG (53). DTH responses were detected in 37 out of 55 patients, but no evidence presented for an antibody or CTL response. Thus, our study is the only one demonstrating that MUC1 conjugated to mannan can generate a humoral response, a $\mathrm{T}$ cell response, and tumor responses (Ong et al., manuscript submitted for publication).

The implications of both humoral and cellular responses in these patients are of interest with respect to tolerance. The studies clearly indicate that humans can make an anti-MUC1 response of both $\mathrm{T}$ and $\mathrm{B}$ cell nature, and that tolerance appears to be broken. In mice, immunization with a self molecule such as Ro and La can break B cell tolerance with more ease than what would be required for breakdown of $\mathrm{T}$ cell tolerance (54); in addition, cancer patients were found to exhibit both humoral and cellular autoreactivity to antigens such as HER-2/ neu and p53 $(55,56)$. The mechanisms controlling such a stringent regulation in the $\mathrm{T}$ cell compartment, however, are not yet understood (57). Perhaps the affinity of the peptide-MHC interaction is an important parameter in self tolerance induction, since low-affinity peptide-MHC interactions can lead to sufficient stabilization of MHC class I complexes exported to the cell surface. This interaction, however, may not lead to tolerance induction during early thymic development (58). In this context, we note that MUC1 peptides presented by HLAA2 have been identified to be of low affinity (46), thus enabling potential autoreactive $T$ cells to escape deletion and remain in the periphery as tightly regulated autoreactive effector cells that may generate autoimmunity when released from these controling mechanisms (59).

It is interesting to note that contrary to the strong cellular and weak antibody responses seen in mice after immunization with M-FP, the patients generated strong antibody responses and moderate cellular responses, findings similar to those generated when monkeys were immunized with human M-FP. We also note that human and monkey MUC1 are similar in 15 of 20 amino acids of the VNTR (Vaughan et al., manuscript submitted for publication). The reasons for the major differences are not clear, but we draw attention to our recent finding that the natural anti-Gal antibodies of humans and monkeys crossreact with human MUC1 $(24,25)$. If this finding is relevant, then it is likely that an ongoing humoral response is further boosted by our immunization to the exclusion of a cellular re- sponse. This finding may have major implications for immunizing patients, however, we have recently found that immunizing mice with primed macrophages can overcome the deviation of the response to antibodies, and we are accordingly planning to use this observation in a clinical setting.

\section{Acknowledgments}

The expert help of Mrs. Helen Gerritsen, data manager and Mrs. Alison Fielding-Price, nurse coordinator, Allamanda Medical Center, is greatly appreciated.

The research was conducted on behalf of a Research and Development Syndicate funded by Meriton Apartments Pty Ltd. and the Austin Research Institute.

\section{References}

1. Taylor-Papadimitriou, J., and S.J. Gendler. 1988. Molecular aspects of Mucins. Cancer Rev. 11:11-24.

2. Hilkens, J., S.V. Lightenberg, H.L. Vos, and S.V. Litvinov. 1992. Cell membrane associated mucins and their adhesion modulating property. TIBS (Trends Biochem. Sci.). 17:359-363.

3. Apostolopoulos, V., and I.F.C. McKenzie. 1994. Cellular mucins: targets for immunotherapy. Crit. Rev. Immunol. 14:293-309.

4. Apostolopoulos, V., G.A. Pietersz, and I.F.C. McKenzie. 1996. Cellmediated immune response to MUC1 fusion protein coupled to mannan. Vaccine. 14:930-938.

5. Gendler, S.J., J.M. Burchell, T. Duhig, D. Lamport, R. White, M. Parker, and J. Taylor-Papadimitriou. 1987. Cloning of partial cDNA coding differentiation and tumor associated mucin glycoproteins expressed by human mammary epithelium. Proc. Natl. Acad. Sci. USA. 84:6060-6064.

6. Siddiqui, J., M. Abe, D. Hayes, E. Shani, E. Yunis, and D. Kufe. 1988. Isolation and sequencing of cDNA coding for the human DF3 breast carcinoma-associated antigen. Proc. Natl Acad. Sci. USA. 85:2320-2323.

7. Wreshner, D.H., M. Hareuveni, I. Tsarfaty, N. Smorodinsky, J. Horev, J. Zaretsky, P. Kotkes, M. Weiss, R. Lathe, A. Dion, and I. Keybar. 1990. Human epithelial tumour antigen cDNA sequences-differential splicing may generate multiple protein forms. Eur. J. Biochem. 189:463-474.

8. Itzkowitz, S.H., M. Yuan, C.K. Montgomery, T. Kjeldsen, H.K. Takahashi, W.L. Bigbee, and Y.S. Kim. 1989. Expression of Tn, sialosyl-Tn and T antigens in human colon cancer. Cancer Res. 49:197-204.

9. Xing, P-X., J. Prenzoska, and I.F.C. McKenzie. 1992. Epitope mapping of anti-breast and anti-ovarian mucin monoclonal antibodies. Mol. Immunol. 29: 641-650.

10. Xing, P.-X., J.J. Tjandra, S.A. Stacker, C.H. Thompson, P.J. McLaughlin, and I.F.C. McKenzie. 1989. Monoclonal antibodies reactive with mucin expressed in breast cancer. Immunol. Cell Biol. 67:183-195.

11. Gendler, S.J., and A.P. Spicer. 1995. Epithelial mucin genes. Annu. Rev. Physiol. 57:607-634.

12. Jerome, K.R., D.L. Barnd, K.M. Bendt, C.M. Boyer, J. Taylor-Papadimitriou, I.F.C. McKenzie, R.C. Bast, and O.J. Finn. 1991. Cytotoxic T-lymphocytes derived from patients with breast adenocarcinoma recognize an epitope present on the protein core of a mucin molecule preferentially expressed by malignant cells. Cancer Res. 51:2908-2916.

13. Barnd, D.L., L.A. Kerr, R.S. Metzgar, and O.J. Finn. 1988. Human tumor-specific cytotoxic T cell lines generated from tumour-draining lymph node infiltrate. Transplant. Proc. 20:339-341.

14. Jerome, K.R., N. Domenech, and O.J. Finn. 1993. Tumour-specific CTL clones from patients with breast and pancreatic adenocarcinomas recognize EBV-immortalized B cells transfected with polymorphic epithelial mucin cDNA. J. Immunol. 151:1654-1662.

15. Ioannides, C.G., B. Fisk, K.R. Jerome, T. Irimura, J.T. Wharton, and O.J. Finn. 1993. CTL from ovarian malignant tumours can recognise polymorphic epithelial mucin core peptides. J. Immunol. 151:3693-3703.

16. Takahashi, T., Y. Makiguchi, Y. Hinoda, H. Kakiuchi, N. Nakagawa, K. Imai, and A. Yachi. 1994. Expression of MUC1 on myeloma cells and induction of HLA-unrestricted CTL against MUC1 from a multiple myeloma patient. $J$. Immunol. 153:2102-2109.

17. Barnd, D.L., M.S. Lans, R.S. Metzgar, and O.J. Finn. 1989. Specific MHC-unrestricted recognition of tumour-associated mucins by human CTL. Proc. Natl. Acad. Sci. USA. 86:7159-7163.

18. Apostolopoulos ,V., P.-X. Xing, and I.F.C. McKenzie. 1994. Murine immune response to cells transfected with human MUC1: Immunisation with cellular and synthetic antigens. Cancer Res. 54:5186-5193.

19. Apostolopoulos, V., G.A. Pietersz, B.E. Loveland, M.S. Sandrin, and I.F.C. McKenzie. 1995. Oxidative/reductive conjugation of mannan to antigen selects for T1 or T2 immune responses. Proc. Natl. Acad. Sci. USA. 92:10128- 
10132

20. Apostolopoulos, V., B.E. Loveland, G.A. Pietersz, and I.F.C. McKenzie. 1995. CTL in mice immunised with human mucin 1 are MHC-restricted. $J$. Immunol. 155:5089-5094.

21. Apostolopoulos, V., P.-X. Xing, J.A. Trapani, and I.F.C. McKenzie. 1993. Production of anti-breast cancer monoclonal antibodies using a glutathione-S-transferase-MUC1 bacterial fusion protein. Br. J. Cancer. 67:713720 .

22. Hodges, R.S., and R.B. Merrifield. 1975. Monitoring of solid phase peptide synthesis by an automated spectrophotometric picrate method. Anal. Biochem. 65:241-272.

23. Kent, S.B.H., and L.E. Hood. 1984. A novel approach to automated peptide synthesis based on new insights into solid phase chemistry. In Peptide Chemistry. A.N. Izumiya, editor. Protein Research Foundation, Osaka, Japan. 217-222.

24. Vaughan, H.A., K.R. Oldenburg, M.A. Gallop, J.D. Atkin, I.F.C. McKenzie, and M.S. Sandrin. 1996. Recognition of an octapeptide sequence by multiple Gal (a1,3)gal-binding proteins. Xenotransplantation. 3:18-23.

25. Sandrin, M.S., H.A. Vaughan, M.A. Gallop, P.-X. Xing, and I.F.C. McKenzie. 1997. Natural human anti-Gal $(\alpha 1,3)$ Gal antibodies react with human mucin peptides. Glycoconj. J. 14:97-105.

26. MacLean, G.D., M.D. Bowen-Yacyshyn, J. Samuel, J. Meikle, G. Stuart, J. Nation, S. Poppena, M. Jerry, R. Koganty, T. Wong, and B.M. Longenecker. 1992. Active immunisation of human ovarian cancer patients against a common carcinoma (TF) determinant using a synthetic carbohydrate antigen. J. Immunother. 11:292-300.

27. Geyson, H.M., S.J. Rodda, T.J. Mason, G. Tribbick, and P.G. Schoofs. 1987. Strategies for epitope analysis using peptide synthesis. J. Immunol. Methods. 102:259-274.

28. Karlsson R., A. Michaelsson, and L. Mattsson. 1991. Kinetic analysis of monoclonal antibody-antigen interactions with a new biosensor based analytical system. J. Immunol. Methods. 145:229-240.

29. Fisk, B., C.G. Ioannides, S. Aggarwal, J.T. Wharton, C.A. O'Brian, N. Restifo, and B.S. Glisson. 1994. Enhanced expression of HLA-A,B,C and inducibility of TAP-1, TAP-2, and HLA-A,B,C, by interferon-gamma in a multidrug-resistant small cell lung cancer line. Lymphokine Cytokine Res. 13:125131.

30. Kotera, Y., J.D. Fontenot, G. Pecher, R.S. Metzga, and O.J. Finn. 1994. Humoral immunity against a tandem repeat epitope of human mucin MUC-1 in sera from breast, pancreatic, and colon cancer patients. Cancer Res. 54:28562860.

31. Apostolopoulos, V., I.F.C. McKenzie, and G.A. Pietersz. 1996. Breast cancer immunotherapy: current status and future prospects. Immunol. Cell Biol. 74:457-464.

32. Xing, P.-X., V. Apostolopoulos, M. Michaels, J. Prenzoska, J. Bishop, and I.F.C. McKenzie. 1995. Phase I study of synthetic MUCI peptides in cancer. Int. J. Oncol. 6:1283-1289.

33. Longenecker, B.M., M.A. Reddish, R.R. Koganty, and G.D. MacLean. 1993. Immune responses of mice and human breast cancer patients following immunization with synthetic sialyl-Tn conjugated to KLH plus detox adjuvant. Ann. NY Acad. Sci. 690:276-291.

34. MacLean, G.D., M.A. Reddish, R.R. Koganty, T. Wong, S. Gandhi, M. Smolnski, J. Samuel, J.M. Nabholtz, and B.M. Longenecker. 1993. Immunisation of breast cancer patients using a synthetic sialyl-Tn glycoconjugate plus Detox adjuvant. Cancer Immunol. Immunother. 36:215-222.

35. O'Boyle K.P., R. Zamore, S. Adluri, A. Cohen, N. Kemeny, S. Welt, K. Lloyd, H.F. Oettgen, L.J. Old, and P.O. Livingston. 1992. Immunization of colorectal cancer patients with modified ovine submaxillary gland mucin and adjuvants induces igm and igg antibodies to sialylated Tn. Cancer Res. 52:56635667.

36. MacLean, G.D., M.A. Reddish, R.R. Koganty, and B.M. Longenecker. 1996. Antibodies against mucin-associated Sialyl-Tn epitopes correlate with survival of metastatic adenocarcinoma patients undergoing active specific immunotherapy with synthetic STn vaccine. J. Immunother. 19:59-68.

37. Rowley, M.J., M.E. Gershwin, and I.R. Mackay 1993. Molecular biology of autoantigens in primary biliary cirrhosis. In The Molecular Pathology of Autoimmunity. C.A. Bona, K. Simonovitch, A.N. Theofilopoulos, and M. Zanetti, editors. Harwood Academic Publishers, Reading, UK. 627-642.

38. Atkinson, M.A. and N.K. Maclaren. 1994. The pathogenesis of insulin dependent diabetes mellitus. N. Engl. J. Med.331:1428-1436.

39. Mosmann, T.R., and R.L. Coffman. 1989. TH1 and TH2 cells: different patterns of lymphokine secretion lead to different functional properties. Annu. Rev. Immunol. 7:145-173.

40. Rughetti, A., V. Turchi, C.A. Ghetti, G. Scambia, P.B. Panici, G. Roncucci, S. Mancuso, L. Frati, and M. Nutti. 1993. Human B-cell immune response to the polymorphic epithelial mucin. Cancer Res. 53:2457-2459.

41. Von Mensdorff-Pouilly, S., M.M. Gourevitch, P. Kenemans, A.A. Verstraeten, S.V. Litvonov, G.J. van Kamp, S. Meijer, J. Vermorken, and J. Hilgers. 1996. Humoral immune response to polymorphic epithelial mucin (MUC-1) in patients with benign and malignant breast tumours. Eur. J. Cancer. 32:13251331

42. Gourevitch, M.M., S. von Mensdorff-Pouilly, S.V. Litvonov, P. Kenemans, G.J. van Kamp, A.A. Verstraeten, and J. Hilgers. 1995. Polymorphic epithelial mucin (MUC-1)-containing circulating immune complexes in carcinoma patients. Brit. J. Canc. 72:934-938.

43. Petrarca, C., A. Rughetti, H. Rahimi, F. D'Agostini, V. Turchi, C. Apollonj Ghetti, G. Scambia, L. Frati, and M. Nutti. 1996. Human antibodies agains the polymorphic epithelial mucin in ovarian cancer patients recognize a novel sequence in the tandem repeat region. Eur. J. Cancer. 32:2155-2163.

44. Burchell, J., J. Taylor-Papadimitriou, M. Boshell, S. Gendler, and T. Duhig. 1989. A short sequence, within the tandem repeat of a cancer-associated mucin, contains immunodominant epitopes. Int. J. Cancer. 44:691-696.

45. Apostolopoulos, V., J.S. Haurum, and I.F.C. McKenzie. 1997. MUC1 peptide epitopes associated with multiple H-2 Class I molecules. Eur. J. Immunol. In press.

46. Apostolopoulos,V., V. Karanikas, J.S Haurum, L.A. Sherman, and I.F.C. McKenzie. 1997. Induction of HLA-A2 restricted cytotoxic T lymphocytes to the MUC1 human breast cancer antigen. J. Immunol. In press.

47. Nakao, M., H. Yamana, Y. Imai, Y. Toh, U. Toh, A. Kimura, S. Yanoma, T. Kakegawa, and K. Itoh. 1995. HLA A2601-restricted CTLs recognise a peptide antigen expressed on squamous cell carcinoma. Cancer Res. 55:42484252

48. Ressing, M.E., W.J. van Driel., E. Celis., A. Sette, R.M.P. Brandt, M. Hartman, J.D.H. Anholts, G.M.T. Schreuder, W. Bram Ter Harmsel, G. Jan Fleuren, B.J. Trimbos, W.M. Kast, and C.J.M. Melief. 1996. Occasional memory cytotoxic $\mathrm{T}$ cell responses of patients with human papilloma virus type 16positive cervical lesions against a human leukocyte antigen-A*0201-restricted E7-encoded epitope. Cancer Res. 56:582-588.

49. Boon, T., and J.C. Cerrotini. 1995. The cell-mediated immune response to tumours. In Oxford Textbook of Oncology, Volume 1. M. Peckham, H Pinedo, and U. Veronesi, editors. Oxford University Press, New York. 73-81.

50. Rammensee, H.-G., T. Friede, and S. Stevanovic. 1995. MHC ligands and peptide motifs: first listing. Immunogenetics. 41:178-228.

51. Redfield, R.R., D.L. Birx, N. Ketter, E. Tramont, V. Polonis, C. Davis, J.F. Brundage, G. Smith, S. Johnson, A. Fowler, et al. 1991. A phase I evaluation of the safety and immunogenicity of vaccination with recombinant gp160 in patients with early human immunodeficiency virus infection. N. Eng. J. Med. 324:1677-1684.

52. Marchand, M., P. Weynants, E. Rankin, F. Arienti, F. Belli, G. Parmiani, N. Cascinelli, A. Bourlond, R. Vanwijck, Y. Humblet, et al. 1995. Tumour regression responses in melanoma patients treated with a peptide encoded by gene MAGE-3. Int. J. Cancer. 63:883-885.

53. Goydos, J.S., E. Elder, T.L. Whiteside, O.J. Finn, and M.T. Lotze. 1996 A phase I trial of a synthetic mucin peptide vaccine. Induction of specific immune reactivity in patients with adenocarcinoma. J. Surg. Res. 63:298-304.

54. Topfer, F., T. Gordon, and J. McCluskey. 1995. Intra- and intermolecular spreading of autoimmunity involving the nuclear self-antigens La (SS-B) and Ro (SS-A). Proc. Natl. Acad. Sci. USA. 92:875.

55. Disis, M.L., E. Calenoff, G. McLaughlin, A.E. Murphy, W. Chen, B. Groner, M. Jeschke, N. Lydon, E. McGlynn, R.B. Livingston, et al. 1994. Existent T-cell and antibody immunity to HER-2/neu protein in patients with breast cancer. Cancer Res. 54:16-20.

56. Houbiers, J.G., H.W. Nijman, S.H. van der Burg, J.W. Drijfhout, P. Kenemans, C.J. van de Velde, A. Brand, F. Momburg, W.M. Kast, and C.J. Melief. 1993. In vitro induction of human cytotoxic T lymphocyte responses against peptides of mutant and wild-type p53. Eur. J. Immunol. 23:2072-2077.

57. Schwartz, R.H. 1993. T cell anergy. Sci. Am. 269:48-54.

58. Fairchild, P.J., and D.C. Wraith. 1996. Lowering the tone: mechanisms of immunodominance among epitopes with low affinity for MHC. Immunol. Today. 17:80-85.

59. Matzinger, P. 1994. Tolerance, danger, and the extended family. Annu. Rev. Immunol. 12:991-1045. 